\title{
COMMENTS AND CAVEATS ON THE WIRE TAPPING CONTROVERSY
}

\author{
RICHARD G. DONNELLY广
}

A RECENT and carefully documented study of wire tapping concluded that although it "is a crime in almost every state, and although there is a federal law prohibiting the interception and divulging of the contents of telephone communications, wire tapping is carried on virtually unimpeded in the United States today." This state of affairs is the culmination of many years of wire tapping history. Except for a one year interlude during World War I, wire tapping was a common practice both in and out of government until 1924 when Attorney General Stone banned tapping by the FBI as "unethical

$\uparrow$ Professor of Law, Yale Law School.

1. Westin, The IVire-Tapping Problens: An Analysis and a Legislatize Proposal, 52 CoL. L. REv. 165, 167 (1952). As a basis for his conclusion Westin summarizes the existing state of affairs as follows:

"A wealth of collected information discloses that the conversations of public officials in every sort of government agency, bureau, and political subdivision have been tapped. Reports are legion that private citizens have had their conversations recorded. All kinds of business organization and social, professional, and political groups have been listed as victims. There are charges that wire tapping may be an essential part of the Federal Bureau of Investigation's population-wide 'loyalty' probe. And recently complaints have been made that telephones of United Nations delegates and employees are under surveillance, as well as the telephones of foreign embassies, legations, and missions in the United States.

"It is not always public officers who use wire tapping to secure information in cases involving kidnapping, murder, narcotics peddling, espionage and the like; telephone monitoring is frequently used by private persons for purposes as diverse as labor espionage and assuring a wife's domestic fidelity. Sometimes the tapping is done by government agencies, by Congressional or state legislative committees, or by rival political administrations. Sometimes tapping of conversations is done by law firms or corporations, and the art is certainly a stock-in-trade of innumerable private detective offices. To facilitate this wire-tapping industry, training centers for instructing telephone tappers have been set up across the country under various sponsurships. Private persons possess, use and even advertise the availability of the instruments necessary for wire tapping."

The legal literature on wire tapping is quite extensive. For other perceptive discussions see Helfeld, $A$ Study of Justice Department Policies on Wire Tapsing, 9 Law. Gumb Rev. 57 (1949) ; Rosenzweig, The Law of II'ire Tappisg, 32 Corsine LQ. 514; 33 CoRNeli L.Q. 73 (1947); Comment, Wirctapping and the Congress, 52 Mrrer. L. Rev. 430 (1954); Note, Congressional IViretapping Policy Ozcrdise, 2 Stas. L. Rew. 744 (1950). Also see Fairfield \& Clift, The Wiretappers, The Reporter, Dec 23, 1952, p. 8 ; Jan. 6,1953 , p. 9. 
tactics." The Stone policy continued in the Department of Justice until 1931 when Attorney General Mitchell announced that the Department would approve wire tapping when requested by the director of the bureall concerned. ${ }^{3}$ For the next nine years the Department of Justice countenanced wire tapping but only in criminal cases of "extreme importance" and never "in minor cases nor on Members of Congress, or officials, or any citizen except where charge of a grave crime had been lodged against him."4 Finally, in 1940, after the Department had lost three test cases ${ }^{5}$ under Section 605 of the Federal Communications Act, Attorney General Jackson announced a return to the Stone policy of 1924 forbidding wire tapping by the FBI. "Under the existing state of the law and decisions," Jackson concluded, wire tapping "cannot be done unless Congress sees fit to modify the existing statutes." But this policy of prohibition lasted for less than a year. In March, 1941, in a letter to the House Judiciary Committee urging the adoption of pending wire tapping legislation, Attorney General Jackson reversed himself with the pronouncement that the "only offense under the present law [Section 605] is to intercept any communication and divulge or publish the same. Any person, with no risk of penalty, may tap telephone wires . . . and act upon what he hears or make any use of it that does not involve divulging or publication."7

This interpretation of Section 605, which is the present position of the Department of Justice, was once described by a congressional committee as

2. Statement of Attorney General Jackson, N.Y. Times, Mar. 18, 1940, p. 1, col. 3, reprinted in full in 86 CoNG. RÉc. App. 1471-2 (1940).

In 1918 the Government seized the telephone and telegraph systems and prohibited in broad terms all wire tapping. "That whoever ... shall, without authority and without the knowledge and consent of the other users . . tap any telegraph or telephone line" should thereby commit a federal offense. 40 STAT. 1017 (1918). This statute expircd by its own terms when control was returned to the private owners in July, 1919. 41 StaT. 157 (1919).

3. Jackson statement, supra note 2 .

4. Ibid.

5. Nardone v. United States, 308 U.S. 338 (1939); Weiss v. United States, 308 U.S. 321 (1939); Nardone v. United States, 302 U.S. 379 (1937). See Westin, supra note 1, at 177.

6. Jackson statement, supra note 2.

7. Hearings before Subcommittee No. 1 of the House Committec on the Jutdiciary on H.R. 2266 and H.R. 3099, 77th Cong., 1st Sess. 18 (1941).

Mr. Rogers attributes this 1941 reversal to "a confidential Presidential directive of May 21, 1940." Rogers, The Case For Wire Tapping, 63 YALE L.J. 792, 795 (1954). That President Roosevelt ever established the present policy has been challenged. Helfeld, supra note 1, at 60 n.34; Barth, The Loyalty of FreE MEN 170-2 (1951). The 1941 statement of President Roosevelt, which Mr. Rogers cites, was an expression of views in response to a bill to authorize wire tapping. This endorsement of a bill to legalize limited wire tapping suggests quite plainly that the President did not consider wire tapping legal in the absence of permissive legislation. Congress did not follow the President's suggestion that legislation be adopted. His advocacy cannot reasonably be construed as an authorization to the Department of Justice to disregard Congress-an authorization he had no power to make. 
"strained and overtechnical." It makes two postulates. First, since the Section uses the terms "intercept ... and divulge or publish," both events must accur before there is a violation. ${ }^{9}$ Second, the entire Federal Government, or at least the Department of Justice, is an entity. Therefore, an investigator does not "divulge or publish" when he passes wire tap information on to his associates and superiors inside the Government. ${ }^{10}$ Apparently, only a disclosure to the world at large constitutes divulgence or publication.

There are a number of holes in the Department's argument. The Supreme Court in the first Nardone case ${ }^{11}$ stated that "the plain words of Section 605 forbid anyone, unless authorized by the sender, to intercept a telephone message, and direct in equally clear language that 'no person' shall divulge or publish the message or its substance to "any person. "12 The only judicial support for the Department's position came in the 1950 dictum of Judge Reeves in the Washington Coplon case. ${ }^{13}$ In the New York Coplon case, on the other hand, both Judge Ryan ${ }^{14}$ and Judge Learned Hand ${ }^{15}$ indicated that interception alone is unlawful. Furthermore, the Department's interpretation ignores the provision of Section 605 which enjoins the "use" of intercepted communications for anyone's benefit. ${ }^{10}$ Obviously, without either divulging or using, wire tapping would be just an idle pastime.17

8. SEN. Rep. No. 2700, S1st Cong., 2d Sess. 5 (1950).

9. Wilful and knowing violations of $\$ 605$ are punishable by a fine of not more than $\$ 10,000$ or by imprisonment for a term of not more than two years or both. 48 Snit. 1100 (1934), 47 U.S.C. $\$ 501$ (1946). Section 605 has been cunstrued to impose a civil as well as criminal liability. Reitmeister v. Reitmeister, 162 F.2d 691 (2d Cir. 1947).

10. Attorney General Biddle stated that to prohibit divulgence was nut to prohibit an investigator from reporting to his superiors. N.Y. Times, Oct. 9, 1941, p. 4, col. 2.

11. Nardone v. United States, 302 U.S. 379 (1937).

12. Id. at 382. Also see United States v. Gruber, 39 F. Supp. 291, 294 (S.D.N.Y. 1911) ("As to the words 'divulge or publish,' I cannot conceive that this refers only to a divulgence in court. The section prohibits divulgence or publication 'to any persun....' The [phrase] 'any person' in the section means exactly what it says, 'any person.' ").

13. United States v. Coplon, 91 F. Supp. S67, 871 (D.D.C. 1950), ree'd on other groasnds, 191 F.2d 749 (D.C. Cir. 1951).

14. United States v. Coplon, SS F. Supp. 921, 925 (S.D.N.Y. 1950) : "The fact that these interceptions were carried on under written authorization of the Attorney General imparts no sanctity to them; they remain unlawful and prohibited."

15. United States v. Coplon, 185 F.2d 629, 636 (2d Cir. 1950): "It is of course wellsettled law that 'wiretapping' is forbidden by statute; and that evidence obtained by a federal officer in violation of law may not be used against the victim of the violation."

16. "[A]nd no person having received such intercepted communication ... shall ... use the same or any information therein contained for his own benefit or the benefit of another not entitled thereto. ..." 48 St.sT. 1103 (1934), 47 U.S.C. \& 605 (1946).

The Supreme Court has yet to be presented with a prosecution for using intercegted data. In Goldstein v. United States, 316 U.S. 114, 122, 125 (1942), toth the majurity and dissenting opinions indicated that the "use for benefit" prohibition was applicable to the Government, its officers, and private persons, and that a violation is punishable as a crime under $\$ 501$. Also see Helfeld, supra note 1, at 64 n.60.

17. See note 20 infra. 
Other federal agencies do not share the Department of Justice's interpretation of Section 605. The Treasury Department, for instance, takes the position that wire tapping itself is prohibited, ${ }^{18}$ and the Federal Communications Commission assumes that since Section 605 prohibits the "use" of information gained by wire tapping, this, in effect, bars any wire tapping. ${ }^{10}$ Faced with a conflict among interested agencies, it is strange that the Department of Justice has never sought a court test of its position in a proceeding where the question could be squarely raised, i.e., a criminal prosecution of a wire tapper. ${ }^{20}$ This failure can perhaps be explained, in part, by a reluctance to prosecute citizens for illegal practices utilized by government agents rather than by any genuine belief in the soundness of the Department's interpretation of Section $605 .{ }^{21}$

Apart from technical objections to the Department's position, its validity is denied by the basic policies which the Supreme Court has ascribed to

18. See Note, 2 Stan. L. Rev. 744 (1950), referring to a letter from the Under Secretary of the Treasury. Even though the Treasury Department does not tap, it has shown considerable resourcefulness in utilizing other electronic devices not proscribed by $\S 605$. See, e.g., On Lee v. United States, 343 U.S. 747 (1952) (walkie-talkie radio); United States v. Sullivan, 116 F. Supp. 480 (D.D.C. 1953) (recording of conversation between informer and suspect).

19. Statement of James L. Fly, Chairman of FCC, to House Judiciary Committec, 88 Cong. Rec. App. 288 (1942). See also, statement of Chairman Hyde of the Federal Communications Commission in Hearings before Subcommittee No. 3, Hause Commiltec on the Judiciary on H.R. 408, H.R. 477, H.R. 3552, H.R. 5149, 83d Cong., 1st Sess. 44 (1953).

20. In the summer of 1950 , when public opinion forced the Department of Justice to proceed against wire tappers in the District of Columbia, the grand jury failed to indict. A congressional investigating committee described this failure as follows:

"The attorneys presenting the case were of the view that unless 'divulgence' of information obtained from wire tapping could be shown, . . . no crime could be made out, though your subcommittee feels that reasonable men could quite well conclude that such wire tapping was hardly engaged in without some divulgence or other use or benefit being made of the information obtained of it." SEN. REP. No. 2700, op. cit. supra note 8, at 5.

There appears to be only one reported case in which the Department prosecuted a violation of $\S 605$. United States v. Gruber, 39 F. Supp. 291 (S.D.N.Y.) (motion to quash indictment and suppress evidence denied), appeal denied, 123 F.2d 307 (2d Cir. 1941). Gruber, an attorney for a client under investigation by the SEC, had induced an SEC switchboard operator to plug him in on calls which affected his client's interests. But this case was not a test of the Department's interpretation, since the defendants had divulged the information.

21. In one instance Attorney General Jackson ordered the United States Attorney for Rhode Island to drop an investigation of wire tapping violations, and the Department reported that it "could not in good conscience' prosecute the wire tappers because the federal investigators had themselves used wire tapping." Westin, supra note 1 , at 169 n.18.

Even if wire tapping alone does not violate $\$ 605$, it still violates the criminal statutes of 38-odd states. Rosenzweig, supra note 1, at 73; Westin, supra at 181 . Moreover, eavesdropping was an indictable offense at common law, $4 \mathrm{BL}$. CoMm. 168 (1890), and 
Section 605, and which Congress has never repudiated. In the first Nardone case, Justice Roberts, adopting the spirit of the Holmes and Brandeis dissents in Olmstead v. United States,"2 formulated these policies:

"Congress may have thought it less important that some offenders should go unwhipped of justice than that officers should resort to methods deemed inconsistent with ethical standards and destructive of personal liberty. The same considerations may well have moved the Congress to adopt $\S 605$ as evoked the guaranty against practices and procedures violative of privacy, embodied in the Fourth and Fifth Amendments of the Constitution." 23

Section 605 thus confers a statutory right of privacy that is equated with the constitutional right of privacy conferred by the Fourth Amendment. Hence, wire tapping is analogous to an unreasonable search and seizure. The argument that telephone privacy is invaded only by interception and divulgence is as fatuous as an argument that Fourth Amendment privacy is invaded only when there is an unreasonable search and seizure and the use of the evidence so obtained in court. Rather the "divulge or publish" provision of Section 605 has the same effect on wire taps as the doctrine of IVeeks $v$. United States, ${ }^{24}$ barring the use of illegally secured evidence, has on unreasonable search and seizure. They are exclusionary rules which supplement civil and criminal sanctions ${ }^{25}$ as means of protecting the right to privacy.

Except as a revealing index to the attitudes and predispositions of the chief investigative and enforcement arm of the Federal Government, the Department of Justice's interpretation of Section 605 is of little assistance in indicating the direction in which reform should move. Its position does make it clear that the existing situation is intolerable and that the confusion over wire tapping will be resolved only when clear and comprehensive legislation is enacted.

Since the first Nardone decision in 1937, nearly 40 bills, resolutions, and joint resolutions dealing with wire tapping have been introduced in Congress. Most of them would have authorized limited wire tapping by federal officials

is still punishable as a statutory offense in some states. Rosenzweig, sipro note $\mathbf{1}$, at $\mathbf{5 3 0}$. As a common law offense, eavesdropping by wire tapping might be considered within the following provision of the District of Columbia Code:

"Whoever shall be convicted of any criminal offense not covered by the provisions of any section of this code... shall be punished by a fine not exceeding one thousand dollars or by imprisonment for not more than five years, or both." D.C. CODE $\$ 22-107$ (Ann. 1951).

22. 277 U.S. $438,449,471$ (192S).

23. Nardone v. United States, 302 U.S. 379,383 (1937).

24. 232 U.S. 383 (1914).

25. The civil and criminal sanctions against an illegal search and seizure are collected by Justice Frankfurter in Wolf v. Colorado, 33S U.S. 25, $30 \mathrm{n.1}$ (1949). For similar sanctions against wire tapping see note 9 supra, and Rosenzweig, supra note 1, at 73. 
and permitted the use of the results in evidence in federal courts. ${ }^{20}$ The bills proposed in the present Congress are basically similar to those of previous years. ${ }^{27}$ Attitudes regarding this legislation depend upon which one of two opposing points of view is embraced. On the one hand, there is the belief that wire tapping should be banned completely and effectively, and that legislation to that end should be adopted. The other approach would authorize limited wire tapping and would prohibit unauthorized taps.

\section{The View that All Wire Tapping Should Be Banned}

This point of view starts with the assumption that wire tapping is an invasion of privacy that cannot be controlled within authorized limits.98 Unlike a search and seizure, which is circumscribed by the provisions of the Fourth Amendment, ${ }^{29}$ a wire tap cannot be specific in its quest for evidence nor confined to matter relevant to crime. It is an exploratory dragnet. It is usually carried on continuously for months on end. It is non-selective and indiscriminate as to whom it "searches" and what it "seizes." 30 In the Coplon

26. See Comment, 52 Mrch. L. Rev. 430, 436 (1954).

27. See H.R. 408, H.R. 477, H.R. 3552, H.R. 5149, 83d Cong., 1st Sess. (1953). Hearings, supra note 19. H.R. 477 was reported favorably to the full committee. Before the full committee, Congressman Keating, the author of H.R. 477, proposed an amendment to his original bill. This was adopted by the full committee and ordered reported in the form of a clean bill, H.R. 8649. See H.R. ReP. No. 1461, 83d Cong., 2d Sess. 1 (1954). See Rogers, supra note 7 , at 792 n.1.

28. This position was first stated in Justice Brandeis' dissent in Olmstead v. United States, 277 U.S. 438, 475-6 (1928) :

"Whenever a telephone is tapped, the privacy of the persons at both ends of the line is invaded and all conversations between them on any subject, and although proper, confidential and privileged, may be overheard. Moreover, the tapping of one man's telephone line involves the tapping of the telephone of every other person whom he may call or who may call him. As a means of espionage, writs of assistance and general warrants are but puny instruments of tyranny and oppression when compared with wire-tapping."

See the Murphy dissents in Goldstein v. United States, 316 U.S. 114, 125 (1942), and Goldman v. United States, 316 U.S. 129, 139 (1942); and the dissents of Justices Frankfurter and Douglas in On Lee v. United States, 343 U.S. 747, 758, 762 (1952).

Senator Joseph McCarthy has apparently endorsed this view. In the current ArmyMcCarthy Investigation, he branded the monitoring of telephone conversations as an "indecent and dishonest" practice. N.Y. Times, April 24, 1954, p. 10, col. 8.

29. For the restrictions imposed by the Fourth Amendment, see Reynard, Freclom from Unreasonable Search and Seizure-A Second Class Constitutional Righti, 25 IND. L.J. 259 (1950); Comment, Limitations on Seizure of "Evidentiary" Objects: A Rule in Search of Reason, 20 U. of CHI. L. REv. 319 (1953).

30. E.g., "In the course of tapping a single telephone, a police agent recorded conversations involving, at the other end, the Julliard School of Music, Brooklyn Law School, Consolidated Radio Artists, Western Union, Mercantile Commercial Bank, scveral restaurants, a drug store, a real estate company, an importer, many lawyers, a stationery storc, a dry cleaner, numerous bars, a garage, the Prudential Insurance Company. . . ." Westin, supra note 1 , at 188 n.112. 
case, ${ }^{31}$ for example, the FBI recorded talks between the defendant and her mother, a quarrel between a husband and wife who had no connection with the case, and conferences between the defendant and her lawyer. ${ }^{32}$ The FBI also learned about an affair, altogether unrelated to espionage, between Miss Coplon and a Justice Department lawyer. ${ }^{33}$

Surely legislation permitting invasions of privacy of this magnitude is justifiable only by great necessity, and the burden of establishing this necessity should be upon the proponents. The proponents of limited wire tapping assert that it is a necessary and important investigative method for the detection and prevention of serious crimes. ${ }^{34}$ And we have the word of Attorney General Brownell that the Justice Department has evidence against "several prople who have betrayed the United States" who cannot be prosecuted because of the ban on wire tap evidence. ${ }^{35}$ The proponents also argue that tapping "is no worse, when used by proper officials and pursuant to adequate safeguards, than is the use of informants, decoys, dictaphones, peeping, and the likeall of which have been accepted practices for many years." 38

But this necessity argument proves too much. It shows the operation of Gresham's law in law enforcement. It substantiates Edmond Cahn's point that one of the important symptoms of "the current atavistic period" is the growing conviction that the process of government must necessarily be a

31. United States v. Coplon, SS F. Supp. 921 (S.D.N.Y. 1950).

32. For the substance of the interceptions, see id. at 926 . Also see, Reporl on cerlais: Alleged Practices of the FBI, 9 LAw. Gunn KEv. 185, 195 (1949).

The interception of telephone communications between attorney and client was held to violate Fifth Amendment due process and Sixth Amendment right to counsel. 191 F.2d 749 (D.C. Cir. 1951).

33. BaRTH, op. cit. supra note 7, at 173.

34. The House Judiciary Committee recently stated its views regarding the need for legislation:

"The existence of an international conspiracy to destroy our form of government is so notorious that it needs no comment. The fact that the agents of this conspiracy are dedicated solely to the overthrow of cur Government by force and violence and are engaged in the commission of such crimes as espionage, sabotage, treason, and other subversive crimes, is patent. The records of our criminal courts substantiate the accuracy of that statement....

"Here are subversive zealots, dedicated to a cause hostile to the very existence of our Government, who are expertly trained to operate within the confines of our country, in secrecy and stealth. They are equipged with the latest technological equipment that science can devise to further their work...

"Our Nation needs today, more than ever, every weapon it can use to destroy those who seek to destroy it. The immunity which the present law gives to these spies and traitors in using a telephone conduit to carry their plans of intrigue and subversion must be stopped." H.R. REP. No. 1461, 83d Cong., 2d Sess. 4, 5 (1954).

35. N.Y. Times, July 27,1953 , p. 10 , col. 4.

36. See Rogers, supra note 7, at 793-4. 
"dirty business," unrestrained by moral considerations. ${ }^{37}$ It runs counter to the principle of our society that the goal of efficiency in law enforcement is subordinate to the preservation of personal liberty. Occasionally, this principle frustrates the true interests of justice by releasing the guilty. But this kind of self-denial on the part of government is an essential characteristic of a free society. Although limited wire tapping may help the FBI bring spies and saboteurs to heel, similar assistance could be expected from opening the mails and practicing the third degree. And, no doubt, a great deal could be learned by placing recording devices in confessionals, in physicians' consulting rooms, ${ }^{38}$ and in lawyers' offices. But a society that countenances these techniques ceases to be free.

Nor does it appear that wire tapping is always a necessary and important investigative method. The Government frequently claims that wire tapping does not yield information of any probative value. ${ }^{30}$ In the Coplon case, in which extensive taps were made, the Government convinced Judge Ryan that the proof to be offered at the trial was independently obtained by other methods of investigation. ${ }^{40}$ And J. Edgar Hoover, in 1940, characterized wire tapping as an "archaic and inefficient" practice which "has proved a definite handicap or barrier in the development of ethical, scientific, and sound investigative techniques." 41

Proponents of wire tapping legislation assert that law enforcement officers would use the limited power wisely. Mr. Rogers, for example, says there is little to fear since the Attorneys General have authorized "relatively few interceptions ... in the past." 42 The joker here is the expression "relatively few." Since there are millions of telephones in this country, the 170 taps admitted by Mr. Hoover to have been in existence on January $15,1950,{ }^{43}$ would probably be considered "relatively few." And while the police may

37. Cahn, Jurisprudence, 29 N.Y.U.L.Q. REv. 473, 481 (1954). Also see Justice Frankfurter's dissent in On Lee v. United States, 343 U.S. 747, 758 (1952).

38. J. Edgar Hoover has stated that physicians should report to the FBI any facts relating to espionage, sabotage, or subversive activity which come to their attention. "The physicians of America, like other citizens can best help in the protection of the nation's internal security by reporting immediately to the FBI any information of this nature which might come into their possession." Hoover, Let's Keep America Strong, $14 \mathrm{~J}$. Ax. MEd. Ass'N 1094, 1095 (1950).

39. See, e.g., United States v. Weinberg, 108 F. Supp. 567, 569 (D.D.C. 1952); United States v. Flynn, 103 F. Supp. 925, 933 (S.D.N.Y. 1951); BAnTHI, op. cil. supra note 7, at 156-170; Note, 61 YALE L.J. 1221 (1952).

40. See United States v. Coplon, 88 F. Supp. 921, 926 (S.D.N.Y. 1950).

41. Letter to the Harvard Law Review, dated Feb. 9, 1940, quoted in 53 Hakv. L. REv. 863, 870 n.53 (1940).

42. See Rogers, supra note 7, at 798.

43. Department of Justice Press Release, Jan. 15, 1950, quoted in Emerson \& Hauen, Political and Civil Rights in the United States, 220-1 n.10 (1952). Attorney Gen* eral Brownell recently told a Senate Judiciary subcommittee that wire tapping operations have reached as many as 200 at a single time since 1941, and that in total they have run into the thousands. N.Y. Times, April 21, 1954, p. 18, col. 1. 
attempt to exercise self-restraint, the influence of power corrupts even the best intentions.

"Experience should teach us to be most on our guard to protect liberty when the Government's purposes are beneficent. Men born to freedom are naturally alert to repel invasion of their liberty by evil-minded rulers. The greatest dangers to liberty lurk in insidious encroachment by men of zeal, well-meaning but without understanding." 4

\section{The View that Liamted Wire Tapping Should Be Authorized}

In the various committee hearings between 1937 and 1941 on proposals to authorize wire tapping, the proponents were generally from the Department of Justice. The opponents usually represented various civil liberties and labor groups. ${ }^{45}$ Most of the opposition disappeared under the stress of World War II and has failed to reappear during the "cold war." 10 It is not unlikely, therefore, that legislation authorizing wire tapping will soon be enacted.47 But legislation committing this nation to a policy of limited vire tapping should be adopted only after careful study and investigation.45 To accommodate the conflicting claims of national security and individual privacy, this legislation should (1) specify a limited number of situations in which wire tapping will be permitted, (2) prescribe dekinite procedures for obtaining permission to wire tap, and (3) impose effective sanctions upon unauthorized wire tapping.

Wire tapping should be restricted to the investigation of a few serious crimes such as treason, sabotage, and espionage." Other "national security or defense" offenses that are essentially sedition laws, such as the Smith

44. Olmstead v. United States, 277 U.S. 438,479 (192S).

45. See Comment, 52 Mire. L. REv. $430,43 S$ (1954).

46. Id. at $438 \mathrm{n} .53$. In the most recent hearings on wire tapping legislation, both the Americans for Democratic Action and the American Federation of Labor endursed limited wire tapping. See the statements of John J. Gunther, Legislative Regresentative, Americans for Democratic Action, and Andrew J. Biemiller, National Legislative Cummittee, American Federation of Labor, in Hearings, supra note 19, at 57, 65. Eut the ADA apparently reversed its position in the Senate Hearings, and opposed even limited wire tapping. N.Y. Times, May 13, 1954, p. 32, col. 1. The American Civil Liberties Uniun and the National Lawyers Guild also opposed limited wire tapping. Hcarisuss, supra note $\mathbf{1 9}$, at $\mathbf{5 3}$, 60. The ACLU, however, realizing that legislation is likely, suggested elaborate safeguards.

47. See Rogers, supra note 7, at 792 n.1.

48. For suggestions as to the scope of such an inquiry, see Helield, $A$ Sludy of the Justice Department Policies On Wire Tapping, 9 LAw. Gund Rev. 57, 68 (1949); Westin, supra note 1, at 200; Comment, 52 MICH. L. Rev. 430, 441 (1954); Note, 2 Srs:. L. REv. 744, 750 (1950).

49. The results of this restricted wire tapping should be admissible in evidence only in the prosecution of one of the specified crimes. Any other disclosure or use should be prohibited. H.R. 8649, 83d Cong., 2d Sess. (1954), permits the use in evidence of authorized taps "in any criminal proceedings in any court established by Act of Congress, but only in criminal cases involving any of the foregoing violations." For the broad category of "violations," see note 51 infra. 
Act, ${ }^{50}$ should not be included. ${ }^{51}$ Sedition laws affect the political process and the range of suspected violators during a time of wild accusations and denunciations is enormous. At a period when the protections afforded to those who question society's values are already sharply curtailed, wire tapping is no weapon to turn loose in the area of political, social, and economic beliefs.

Even in the investigation of the limited class of crimes enumerated, strict and definite procedural safeguards should be observed before wire tapping is authorized. Although the Department of Justice insists that the Attorney General should have the exclusive authority to permit wire taps, judicial control is an essential safeguard. The Attorney General is obviously an interested party and should not be charged with policing his own investigations.52 Otherwise, if the FBI asserts that "national security" is at stake, permission is likely to be accorded automatically. It would be interesting to know whether the Attorney General under present practice has ever turned down an FBI request.

Since wire tapping, like a search and seizure, is a governmental inquiry into the privacy of an individual's affairs, it requires the supervision of the courts. The power to issue ex parte orders authorizing wire tapping should be deposited in the federal judiciary. These orders should be issued if the Attorney General's application shows (1) probable cause to believe that one of the specified crimes has been committed or is about to be committed, (2) probable cause to believe that evidence will be obtained essential to the solution of such crime, or which may prevent its commission, and (3) that there are no other means readily available for obtaining such information. ${ }^{\text {b3 }}$

50. 62 StAT. 808 (1948), 18 U.S.C. $\$ 2385$ (Supp. 1951).

51. H.R. 8649, 83d Cong., 2d Sess. (1954), permits wire tapping upon the express written approval of the Attorney General and "in the course of any investigation to detect or prevent any interference with or endangering of . . . the national security or defense ... by treason, sabotage, espionage, sedition, seditious conspiracy, violations of chapter 115 of title 18 of the United States Code ... , violations of the Internal Security Act of $1950 \ldots$. . violations of the Atomic Energy Act of 1946 . . . , and conspiracies involving any of the foregoing." Chapter 115 of title 18 covers the crimes of treason, misprision of treason, rebellion or insurrection, seditious conspiracy, and advocating overthrow of Government. It also deals with certain offenses affecting the armed services.

52. Cf. Statement of Miles McDonald, Hearings, supra note 19, at 71, 80:

"Mr. McDonald. I think prosecutors, myself included, can be overzealous; and I think you sometimes get to a point where you have pretty good suspicion, but no evidence, and you want to rush in and get a wiretap. You think you will solve everything with a wiretap and you are inclined to do it; it is a shortcut.

"I think someone who was disinterested in the success of the prosecution ought to be a safeguard that will go in and say, "You have not got enough." "

53. This follows rather closely the New York procedure. See Westin, supra note 1, at 203, and the statement of Miles F. McDonald, District Attorney of Kings County, Brooklyn, N.Y. in Hearings, supra note 19, at 71-91. 
The Department of Justice opposes court control for several reasons. First, wire tapping requires a high degree of secrecy, and leals can best be avoided by placing it under the control of the Attorney General. Second, uniformity in authorization is necessary, and this would be jeopardized if several hundred federal judges could issue court orders. Third, speed is essential and the time consumed in obtaining a court order might result in the loss of important evidence. With the possible exception of lack of uniformity, these fears have not materialized in New York where wire tapping is permitted pursuant to an ex parte court order. ${ }^{\text {Ds }}$ And lack of uniformity would gradually disappear as the courts worked out the criterin for determining the meaning of "probable cause." Furthermore, it is not necessary that every federal judge be granted the power to issue wire tapping orders. Since permission to tap would be requested in "relatively few" cases, the authority might be limited to the federal judges in the District of Columbia ${ }^{60}$ or to judges designated by the Chief Judge of each circuit.

Finally, limited wire tapping legislation should effectively interdict unauthorized tapping. ${ }^{57}$ The first step is to remove the ambiguities in Section 605 : it should be made clear that the act of wire tapping is illegal. Mloreover, wire tapping should be redefined. Section 605 uses the term "intercept," and narrow judicial construction has held that telephone conversations picked up on a detectaphone were not intercepted. ${ }^{58}$ The placing of a recording device

54. See Statement of William P. Rogers, Deputy Attorney General, in Hcarings, sispra note 19 , at 4,5 .

55. See Statement of Miles McDonald, in Hearings, supro note 19, at 71-91.

"Mr. Keating. But so far as leakages in the court are concerned, have you ever had any bad experience?

MR. MICDonald. Never." Id. at \$2.

56. Rule 41 (a) of the Federal Rules of Criminal Procedure limits the power to issue a search warrant to the district wherein the property sought is located. Weinberg $v$. United States, 126 F.2d 1004 (2d Cir. 1942), indicated that Art. III, \$2, of the Constitution and the Sixth Amendment require such a limitation on a district court's power.

"Though these [constitutional] provisions refer to the trial, no one has yet attempted to separate process from trial and make the former eitend beyond the district." Id. at 1006.

On the other hand, an arrest warrant may be served anywhere in the Unitcd States, Rule 4 (c) (2), thus modifying the former practice under which a varrant could be served only within the district where issued. Mitchell v. Dester, 244 Fed. 926 (1st Cir. 1917). And under Rule 17 (e) a subpoena requiring the attendance of a witness may be served anywhere in the United States.

57. Criminal sanctions for unauthorized tapping are not the only methods of control. Section 552-a of the New York Penal Law, recognizing the extreme difficulty of apprehending the wire tapper as he is tapping a line, malies the possession of wire tapping equipment by private persons and unauthorized public officers a crime. And for the recommendation that the Federal Communications Commission be empovered to malse rules and regulations governing wire tapping, and also be granted certain investigative and enforcement powers, see Westin, supra note 1, at 207.

58. Goldman v. United States, 316 U.S. 129 (1942). 
on one end of the line has also given the federal courts some trouble. ${ }^{50}$ And it is not clear whether the use of an induction coil is an interception. ${ }^{00}$ Wire tapping should be defined in such a way as to include all possible devices and techniques for invading wire privacy by listening to the contents of a telephone message.

\section{CONCLUSION}

It is by no means clear that the proponents of limited wire tapping have shown its necessity. But even if the view that all wire tapping should be banned prevails, new legislation is needed because Section 605 is inadequate. On the other hand, if the limited wire tapping position is accepted, it is essential that wire tap investigations be limited to a few serious crimes, that the results be admissible in evidence only in the prosecution of these crimes, that court authorization of tapping be required, and that the public be afforded realistic protection against unauthorized wire tapping. The bills proposed in the current session do not meet these standards.

59. Compare United States v. Polakoff, 112 F.2d 888 (2d Cir. 1940), with United States v. Sullivan, 116 F. Supp. 480 (D.D.C. 1953).

Following the Polakoff case the Federal Communications Commission in 1947 issued a regulation requiring that every telephone-recorder attachment, when in operation, must emit a "beep" warning signal over the wires each fifteen seconds. Today, with the production of telephone recorders thriving, there are at least a hundred thousand in active use, mostly in private industry but a substantial number in government. Less than ten per cent of these-the Bell System's most recent figure is eight thousand-give the required "beep." Fairfield \& Clift, stipra note 1, at 8, 12 .

A related problem arose in the Army-McCarthy Investigation. There, the dispute was whether or not stenographic reports of telephone conversations could legally be presented to the congressional committee for its consideration. N.Y. Times, April 25, 1954, §1, p. 1, col. $1 ; \S 4$, p. 1 , col. 7 .

60. In Schwartz v. Texas, 344 U.S. 199 (1952), the Supreme Court assumed without deciding that use of an induction coil constituted an interception, but held that $\S 605$ was not intended to ban wire tap evidence in state courts.

Most writers agree that Congress has power to regulate the use of wire tapping cvidence in state as well as federal courts. Rosenzweig, supra note 1, at 77; Notes, 34 ILL. L. Rev. 758, 760 (1940); 40 J. Crim. L. \& Criminology 476, 481 (1949); 25 Minn. L. REv. 382, 384 (1941). This problem should be considered in drafting wire tapping legislation. See Comment, 52 MicH. L. REv. 430 (1954). 


\section{THE YALE LAW JOURNAL}

VoLUME 63

APRIL, 1954

TUMrber 6

RICHARD A. SIEGAL

Article and

Book Review Editor

WILIIAM BARONOFF

Robert WMr. Berend

RICHARD K. BeRg

Murry David Brochin

BARRY R. BRYAN

Thonras N. Carruthers, Jr.

Jeroxie A. Conen

Donazd J. Cohn

LEWIS G. COLE

John W. Colleran

Williax H. Dearpsey, JR.

Russerl C. Dilks

Davin A. Drexier

S. Gornon ElkiNs

KIAUS EPPLER
EDITORIAL BOARD

DAVID R. HYDE

Editor-in-Chief

Masvin Katz

David R. TIllinghast

JoN R. WALTZ

Note and Comment Editors

Joseph M1. Fietd

Bernard FINEELSTEIN

JosepH B. GILDENHORN

Alan Gladstone

Howard Aldin Glichstein

Norsian S. Goldsurrtr

Harold Grabino

ANNE GRoss

Charles S. Haight, Jr.

Eltiot Lee Hoffssax

Alexander P. Hoffrians

ROBERT L. LASKY

Noel ArNold Lewn

Charles S. Mechear, Jr.

Thonas F. Nelson
PAYSON WOLFF

Managing Editor

LAWRE:CE Newana:

STUATT ML. PALE:

Alvm H. Scrutsan:

Jentise Rutchie SILVER

MLomioe Stuterisart

Ricenno S. Siansozts

DAmies. MI. Smger

Gorron B. Spryack

Melvis Stem:

STEpaE: W. Tourt

Gerald Warpr:

Roger A. WEICE

PAUL R. WELTCEEI

HASOLD MI. WIT

Grorge C. Znchasy

Marie Mcilahon

Business Secrefary

\section{CONTRIBUTORS TO THIS ISSUE}

Mrron Seanrer. B.A. 1939, University of California at Los Angeles; LL.B. 1943, Harvard University. Member, New York Bar.

Mruton H. Stekn. A.B. 1943, Lafayette College; LL.B. 1948, Columbia University. Member, New York Bar.

Lawrence JARetr. B.S. 1936, LL.B. 1939, St. John's University; 11.A. 1940, LL.M. 1949, J.S.D. 1952, New York University. Associate Professor of Alaritime and International Law, U.S. Merchant Marine Academy. Member, New York Bar.

Willianr P. Rogers. A.B. 1934, Colgate University; LL.B. 1937, Corncll University. Deputy Attorney General of the United States. Chief Counsel, Senate Investigations Subcommittee of the Senate Executive Expenditures Committee, 1948-50. Chief Counsel, Senate War Investigating Committee, 1947-8. Assistant District Attorney, Nev York County, 1938-42. Member, New York and District of Columbia Bars.

Richard C. Donnetiy. Ph.B. 1936, LL.B. 1938, Washburn University; J.S.D. 1949, Yale Law School. Professor of Law, Yale Law School. 